\title{
The Diffusion of Carbon Monoxide out of Cigarettes*
}

\author{
by R. R. Baker and R. A. Crellin \\ Group Research and Development Centre, British-American Tobacco Co. Ltd., \\ Southampton, England
}

\section{INTRODUCTION}

The mean concentration of carbon monoxide in its formation region inside a burning cigarette is typically about $7-10 \% \quad v / v(1-3)$. Examination of the distribution of carbon monoxide inside the cigarette shows that its concentration decreases behind the formation regions. Waltz and Häusermann (4) have shown that about $35 \%$ of the carbon monoxide drawn down the tobacco rod to form the mainstream smoke is lost during the early puffs, for cigarettes wrapped with paper of permeability $250 \mathrm{~cm}^{3} \mathrm{~min}^{-1}\left(10 \mathrm{~cm}^{2}\right)^{-1}(10 \mathrm{~cm} \text { water })^{-1}$. Specifically, the study indicated that about one fifth of this decrease was due to air entering through the cigarette paper and diluting the puff, while the remaining four fifths of the decrease was due to the gases diffusing out of the tobacco rod.

Several studies have demonstrated that carbon monoxide can diffuse out of a tobacco rod (1, 4 and 5). Owen and Reynolds (6) have shown that the mainstream carbon monoxide concentration decreases exponentially with length of tobacco rod exposed to air, in accordance with an expression based on Fick's first law of onedimensional diffusion. The validity of this relationship has been confirmed in other studies (3). These studies tacitly assume that the main resistance to the outward diffusion of gases is the cigarette paper. However, a theoretical study by Imazu (7) suggests that the main resistance is that of diffusion through the tobacco bed itself.

Thus the effect of diffusion of gases out of the tobacco rod can be considerable, and in some cigarette designs it is more important than air dilution in controlling the carbon monoxide mainstream delivery. The present paper examines some of the factors that affect the diffusion of carbon monoxide out of the tobacco rod.

\footnotetext{
- Presented, in part, at the 30th Tobacco Chemists' Research Conference, Nashville, Tennessee, U.S.A., October 1976.
}

\section{Diffusion and Dilution Equation}

By applying Fick's law of one-dimensional diffusion to an isothermal gas mixture moving through a tobacco rod in a manner similar to that of Owen and Reynolds (6), and including the following factors:

[1] the flow of diluting air through the paper,

[2] diffusion cannot occur through the impervious region of overlapping paper in the tobacco rod, and

[3] diffusion occurs through the tobacco bed, the paper, and away from the outer paper surface into the atmosphere,

it can be shown that:

where

$$
[\mathrm{CO}]=[\mathrm{CO}]_{0} \frac{\mathrm{V}_{0}}{\mathrm{~V}_{\mathrm{T}}} \exp \left\{-\frac{(2 \pi \mathrm{r}-\mathrm{q})}{\varepsilon \pi \mathrm{r}^{2}} \frac{\mathrm{GL}}{\mathrm{ux}}\right\},
$$

$[\mathrm{CO}],[\mathrm{CO}]_{0}$ are the carbon monoxide concentrations at the exit and inlet of the tobacco rod respectively $(\% \mathrm{v} / \mathrm{v})$,

$\mathrm{V}_{0}, \mathrm{~V}_{\mathrm{T}}$ are the total gas flow rates into the tobacco rod, and out of the mouth end, respectively $\left(\mathrm{cm}^{3} \mathrm{~s}^{-1}\right)$,

$r$ is the cigarette radius $(\mathrm{cm})$,

$\mathrm{q}$ is the amount of impervious paper overlap (cm),

$\varepsilon$ is the fraction of the tobacco rod occupied by air,

$\mathrm{L}$ is the length of tobacco rod exposed to air ( $\mathrm{cm})$,

$\mathbf{x}$ is the paper thickness $(\mathrm{cm})$,

$\mathbf{u}$ is the mean linear gas velocity through the tobacco $\operatorname{rod}\left(\mathrm{cm} \mathrm{s}^{-1}\right)$, and

$G$ is a function having the dimensions of diffusion coefficient $\left(\mathrm{cm}^{2} \mathrm{~s}^{-1}\right)$, dependent on:

[a] radial diffusion through the tobacco bed,

[b] diffusion through the cigarette paper, and

[c] diffusion away from the outer surface of the paper. 
The equation is approximate since its derivation does not take account of the detailed gas velocity distribution in the tobacco rod as the gas mixture is sucked through it, and a concentration boundary layer is assumed to exist inside the tobacco rod, between the surface of the paper and the bulk gases inside the rod. Consequently, the air dilution effects, and the gas diffusion through the tobacco bed, have only been treated approximately. The full equations which include these effects more accurately are complex, and can only be solved using a numerical procedure by computer program. Nevertheless, the above equation will suffice for the present paper since it describes the features of the diffusion model in broad terms.

In equation 1 , the mean linear gas velocity through the tobacco bed ( $u$ ) is equal to $\nabla / a$, where $\nabla$ is the mean flow of gas through the cigarette $\left(\mathrm{cm}^{3} \mathrm{~s}^{-1}\right)$ and $a$ is the effective area of cross section of the cigarette through which the gas can flow. If the air spaces between the tobacco strands are distributed evenly along the diameter and length of the cigarette, a will be equal to $\sqrt{\varepsilon} \pi r^{2}$. Measurements of the density of flue-cured tobacco with an air comparison pycnometer (8), and studies involving radioactive argon (9), give the fraction of the tobacco rod occupied by air $(\varepsilon)$ a value of about 0.85 .

Rearrangement of equation 1 , with the above substitution for $u$, gives:

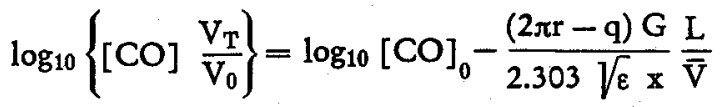

Equation 2 predicts that a plot of $\log _{10}\left([\mathrm{CO}] \mathrm{V}_{\mathrm{T}} / \mathrm{V}_{0}\right)$ against $\mathrm{L} / \nabla$ will be linear, with a negative gradient, if both diffusion and air dilution effects are occurring. If air dilution only is occurring, i. e. $G=0$, the gradient of the plot will be zero.

\section{EXPERIMENTAL DETAILS}

The non-filter cigarettes used contained a typical English-type Virginia blend tobacco, and were usually $69 \mathrm{~mm}$ long and $8 \mathrm{~mm}$ in diameter. The cigarette paper was about $38 \mu \mathrm{m}$ in thickness, and the amount of impervious paper overlap was $2 \mathrm{~mm}$. Unless otherwise stated, the cigarette paper had a permeability of $70 \mathrm{~cm}^{3}$ $\min ^{-1}\left(10 \mathrm{~cm}^{2}\right)^{-1}(10 \mathrm{~cm} \text { water })^{-1}$, as measured with a Wiggins Teape Air Permeability Tester Mark IIA $(1 \mathrm{~cm}$ water $\left.=98 \mathrm{~N} \mathrm{~m}^{-2}\right)$. The cigarettes were weight $(1.00 \pm$ $0.01 \mathrm{~g}$ ) and pressure drop (3\% variation) selected, and conditioned at $21^{\circ} \mathrm{C}$ and $60 \%$ relative humidity.

In the experiments using unlit cigarettes, a mixture of $9.6 \% \mathrm{v} / \mathrm{v}$ carbon monoxide in nitrogen was drawn through the cigarette by a small vacuum pump. Different lengths of the central portion of the cigarette were exposed to air by wrapping impervious vinyl tape round the remainder of the tobacco rod. Carbon monoxide concentrations were measured with a Bosch infra-red analyser, type EFAW 215. Total gas flows into and out of the cigarette were measured with rotameters or bubble meters.

Unless otherwise stated, the experiments were performed under conditions where there was an external air movement of $80 \mathrm{~cm} \mathrm{~s}^{-1}$ across the cigarette.

\section{RESULTS AND DISCUSSION}

\section{Diffusion and Dilution Equation}

The results obtained with an unlit tobacco rod, plotted according to equation 2, are given in Figure 1, for various flow rates of $9.6 \% \mathrm{v} / \mathrm{v}$ carbon monoxide in nitrogen drawn through the cigarette. The plots have negative gradients, confirming that diffusion out of the tobacco rod is occurring. In fact for the relatively low permeability paper used in this experiment, the air dilution factor $\mathrm{V}_{\mathrm{T}} / \mathrm{V}_{0}$ made a maximum contribution of only $7 \%$ to the decrease in carbon monoxide concentration as the gas mixture was drawn through the cigarette at the largest length of exposed tobacco rod $(5.5 \mathrm{~cm})$. For a cigarette wrapped in this paper, the major decrease in carbon monoxide concentration is due to loss by outward diffusion.

The results in Figure 1 show that the gradient of the plot (and hence G) is dependent on the total gas flow rate inside the cigarette. The value of $G$ increases from $1.46 \times 10^{-3} \mathrm{~cm}^{2} \mathrm{~s}^{-1}$ to $1.89 \times 10^{-3} \mathrm{~cm}^{2} \mathrm{~s}^{-1}$ as $\nabla$ increases

Figure 1. Diffusion of carbon monoxide out of unllt tobacco rod.

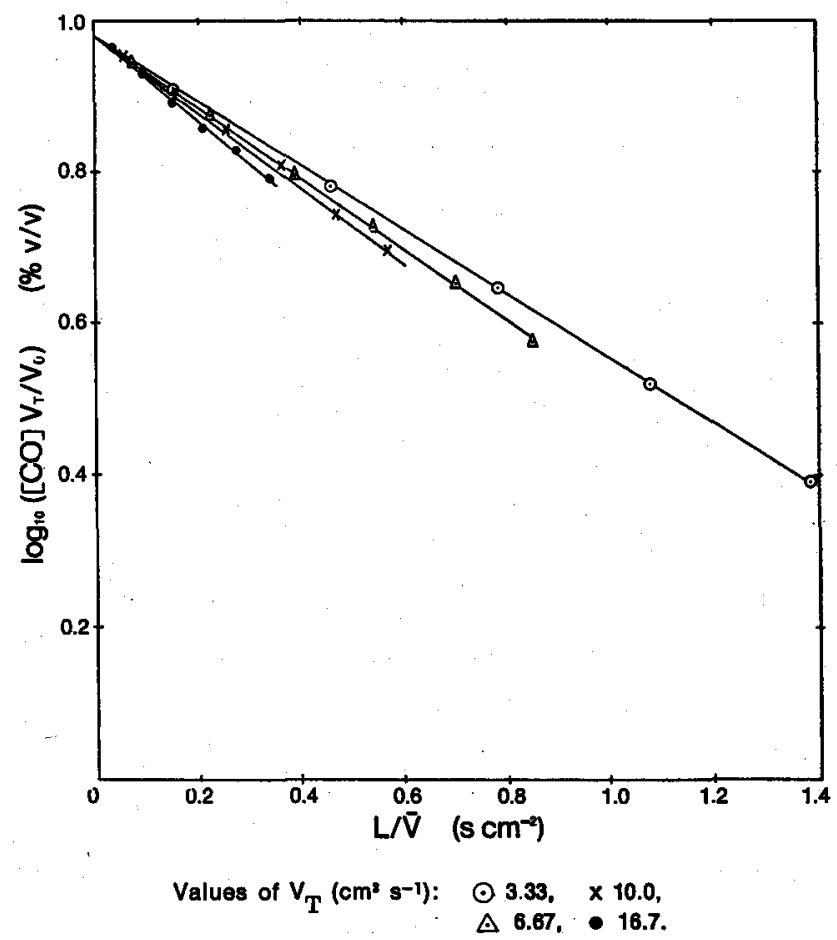


from 3.25 to $16.2 \mathrm{~cm}^{3} \mathrm{~s}^{-1}$. This variation between $\mathrm{G}$ and $\nabla$ can be empirically summarised in either of two equations:

$$
\begin{aligned}
& \mathrm{G}=1.21 \times 10^{-8}(\nabla)^{0.16}, \\
& \mathrm{G}=\frac{1}{(570 / \nabla)+509} .
\end{aligned}
$$

In terms of the theory used to derive equation 2, outlined above, the relationships in equations 3 or 4 reflect a decrease in the thickness of the concentration boundary layer between the inner surface of the cigarette paper and the bulk gases in the tobacco rod, as the gas flow inside the tobacco rod increases. However, as mentioned above, this theory is approximate, and it is not profitable to analyse the significance of equations 3 and 4 further. In general, it may be stated that the increase of $G$ with gas flow is due to an increase in the radial carbon monoxide concentration gradients in the tobacco bed.

The diffusion coefficient $\left(D_{p}\right)$ through the low permeability cigarette paper used to obtain the results in Figure 1 has a value of $4.4 \times 10^{-3} \mathrm{~cm}^{2} \mathrm{~s}^{-1}$ (method of determination described later). Consequently the much lower value of $\mathrm{G}$ indicates the importance of diffusion through the tobacco bed, and diffusion away from the outer surface of the paper.

The results obtained with the tobacco rod smoked at a continuous draw of $2.0 \mathrm{~cm}^{3} \mathrm{~s}^{-1}$, plotted according to equation 2 with the cigarette wrapped in the same paper of permeability about $70 \mathrm{~cm}^{3} \mathrm{~min}^{-1}\left(10 \mathrm{~cm}^{2}\right)^{-1}$ $(10 \mathrm{~cm} \text { water })^{-1}$, are shown in Figure 2. The mainstream smoke was passed through a Cambridge filter, and the filtered smoke was drawn through the Bosch infra-red analyser, where the carbon monoxide concentration was continuously monitored. In these experiments, [CO ]a was that produced by the burning tobacco. Each of the individual points in Figure 2 was obtained by averaging the results of at least six experiments (total variation was about $\pm 5 \%$ ). The linearity of the plot is very good at values of $\mathrm{L} / \nabla$ greater than about $0.8 \mathrm{~s} \mathrm{~cm}^{-2}$. The characteristic curvature observed on the plot for small values of $L / \nabla$ corresponds to a distinct wetting of the cigarette paper towards the latter stages of the smoking, when the length of exposed tobacco rod was less than $15 \mathrm{~mm}$. This wetting, caused by the accumulation of condensing material in the cigarette butt, effectively sealed the pores in the cigarette paper so that carbon monoxide was prevented from diffusing out of the cigarette rod radially.

The gradient of the linear portion of the plot in Figure 2 gives $G$ a value of $1.9 \times 10^{-8} \mathrm{~cm}^{2} \mathrm{~s}^{-1}$. Extrapolation of the variation of $G$ with $\nabla$ for the unlit tobacco rod gives $G$ a value of $1.3 \times 10^{-3} \mathrm{~cm}^{2} \mathrm{~s}^{-1}$ at $V_{\mathrm{T}}=2.0 \mathrm{~cm}^{3} \mathrm{~s}^{-1}$. The much larger value of $G$ from the lit cigarette must be due to thermal effects. The molecular diffusion coefficient is proportional to (temperature) ${ }^{1.75}$ and under continuous draw conditions the gas temperatures inside the cigarette are greater than $50^{\circ} \mathrm{C}$ for $17 \mathrm{~mm}$ behind the paper burn line of the combustion coal $(2,10)$. Thus
Figure 2. Concentration of carbon monoxide in mainstream smoke of clgarette smoked at a continuous draw of $2.0 \mathrm{~cm}^{3} \mathrm{~s}^{-1}$.

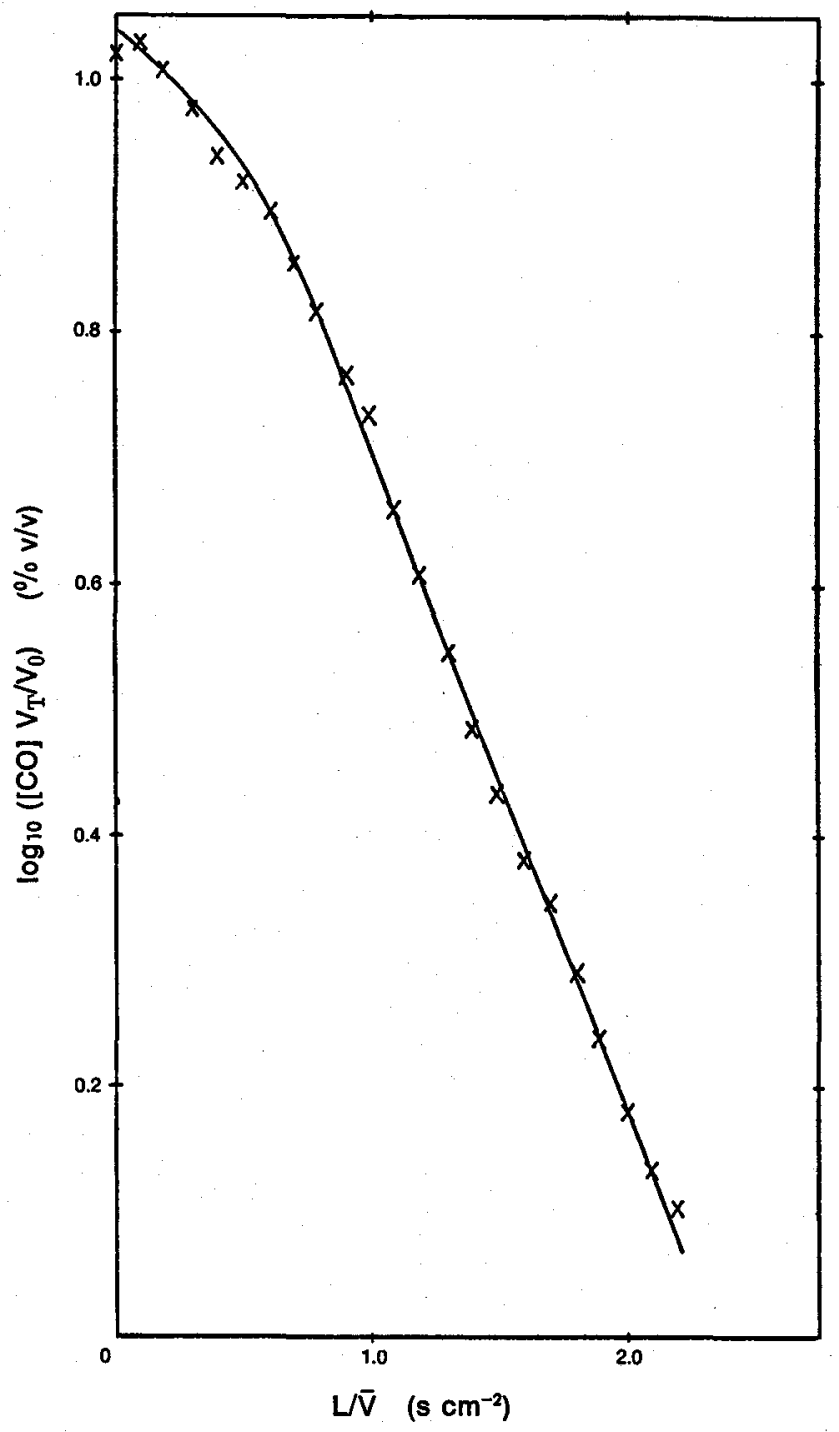

molecular diffusion in the tobacco bed will be greater in the lit cigarette than in the unlit cigarette. Thermal diffusion itself is probably unimportant in the relatively small temperature gradients that exist in the majority of the unburnt tobacco rod.

The results obtained with the tobacco rod smoked under puffing conditions are shown in Figure 3. These results are the mean of ten cigarettes smoked singly on a Cigarette Components $\mathrm{Ltd}$. CSM 10 smoking machine, taking a $35 \mathrm{~cm}^{3}$ puff of 2 seconds duration once per minute, under restricted smoking conditions. The pressure-time profile of the puff was square. The total variation of the individual results was $\pm 10 \%$.

Again, the negative gradient of the line in Figure 3 confirms that diffusion of carbon monoxide out of the tobacco rod is occurring. The gradient gives $G$ a value of $2.8 \times 10^{-3} \mathrm{~cm}^{2} \mathrm{~s}^{-1}$. Extrapolation of the variation of $G$ with $\nabla$ for the unlit tobacco rod gives $G$ a value of $1.8 \times 10^{-8} \mathrm{~cm}^{2} \mathrm{~s}^{-1}$ at $\mathrm{V}_{\mathrm{T}}=17.5 \mathrm{~cm}^{3} \mathrm{~s}^{-1}$. Thus the larger value of $G$ from the lit cigarette must be due to thermal effects. 
Figure 3. Concentration of carbon monoxide In mainstream smoke of clgarette smoked under puffing conditions.

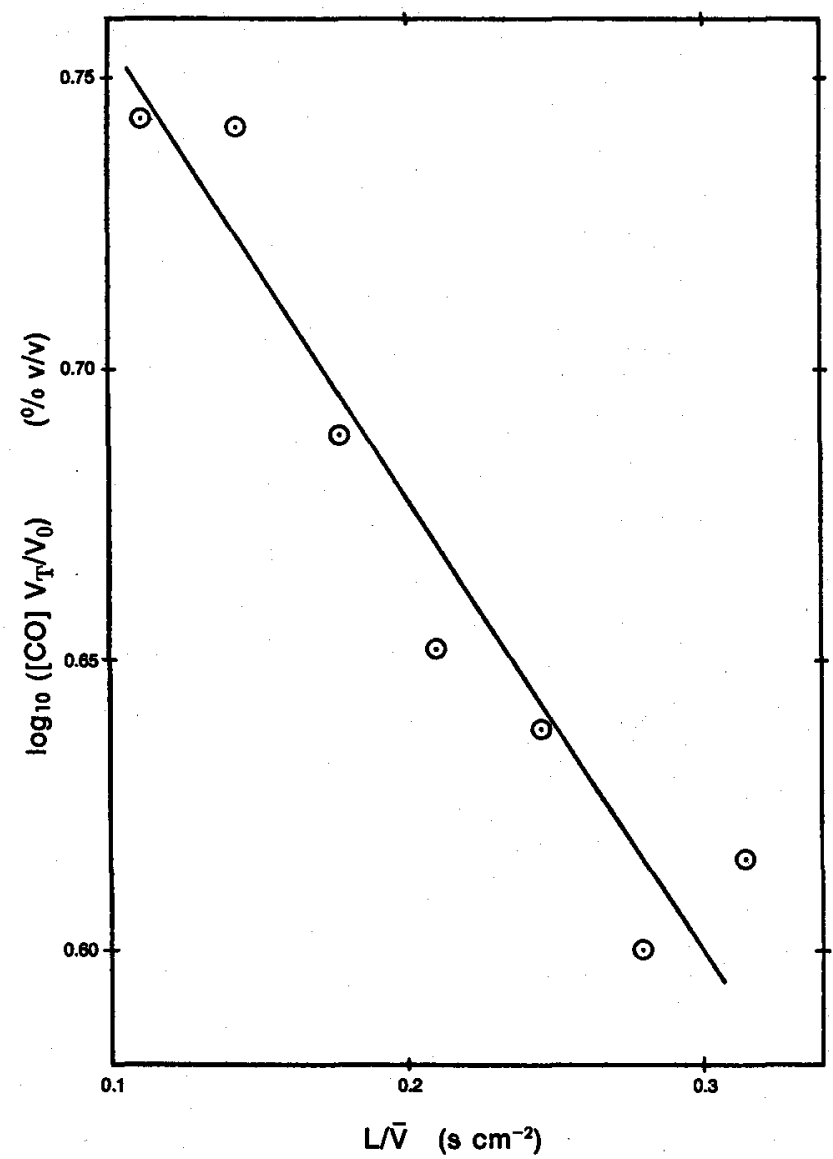

Figure 4. Decresse in carbon monoxide concentration in malnstream smoke of clgarette smoked under puffing conditlons, due to dilution and to diffusion.

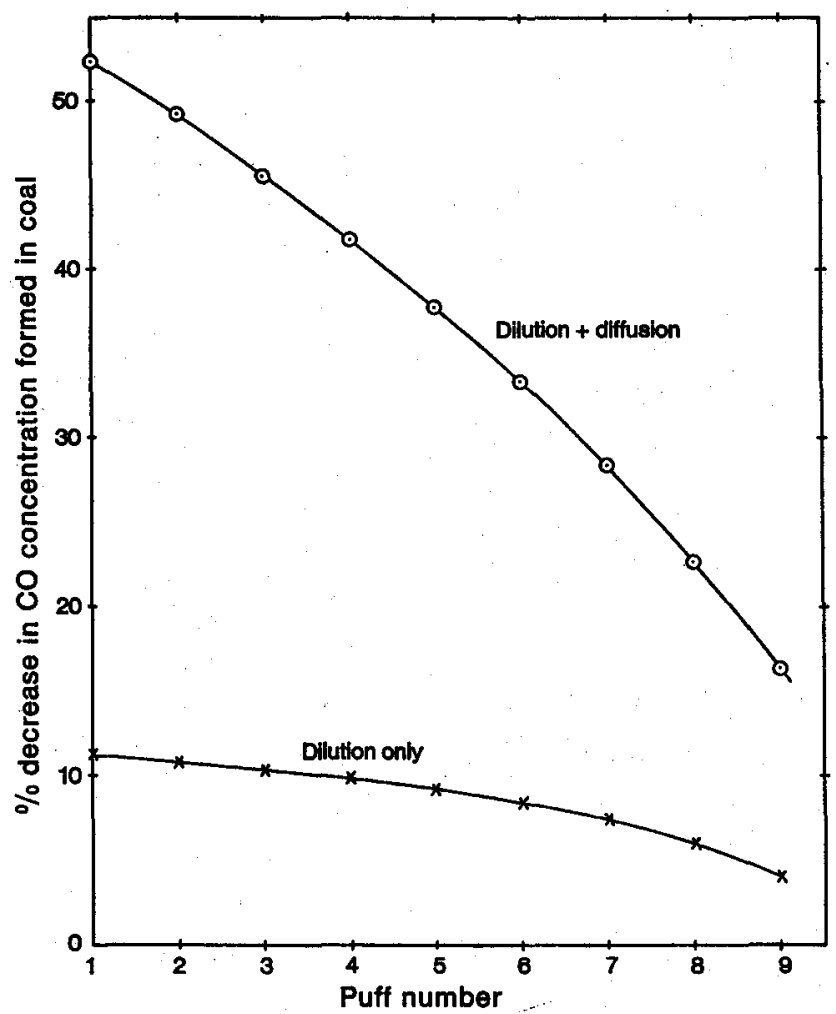

It is interesting to examine the results in Figure 3 in more detail, to see the exact contributions of dilution and diffusion to the decrease in carbon monoxide concentration, as the cigarette is smoked. From equation 1, the percentage decrease in carbon monoxide formed in the coal due to diffusion out of the tobacco rod and air dilution into the rod is given by:

$$
\begin{aligned}
& (\% \text { decrease })_{\text {diff }+ \text { dil }}= \\
& =\left\{1-\frac{V_{0}}{V_{T}} \exp \left[-\frac{(2 \pi r-q)}{\sqrt{\varepsilon}} \frac{G L}{x \bar{\nabla}}\right]\right\} 100 .
\end{aligned}
$$

If air dilution effects only are occurring, i.e. $G=0$, equation 5 reduces to:

$$
(\% \text { decrease })_{\text {dil }}=\left(1-\mathrm{V}_{0} / \mathrm{V}_{\mathrm{T}}\right) 100 .
$$

Thus using the value of $\mathrm{G}=2.8 \times 10^{-3} \mathrm{~cm}^{2} \mathrm{~s}^{-1}$, obtained from the gradient of the plot in Figure 3, the decreases in carbon monoxide concentration due to diffusion and dilution, and to dilution only, are given in Figure 4 as a function of puff number. Clearly, for the particular cigarette and conditions used, diffusion is by far the most important factor in determining the final mainstream concentration of carbon monoxide.

\section{Diffusion and Dilution Effects}

The exact effects of tobacco rod length, flow rate, paper permeability and external air movement on the magnitudes of diffusion and dilution are examined in more

Figure 5. Diffusion of carbon monoxide out of unlit tobacco rods at different $V_{T^{*}}$

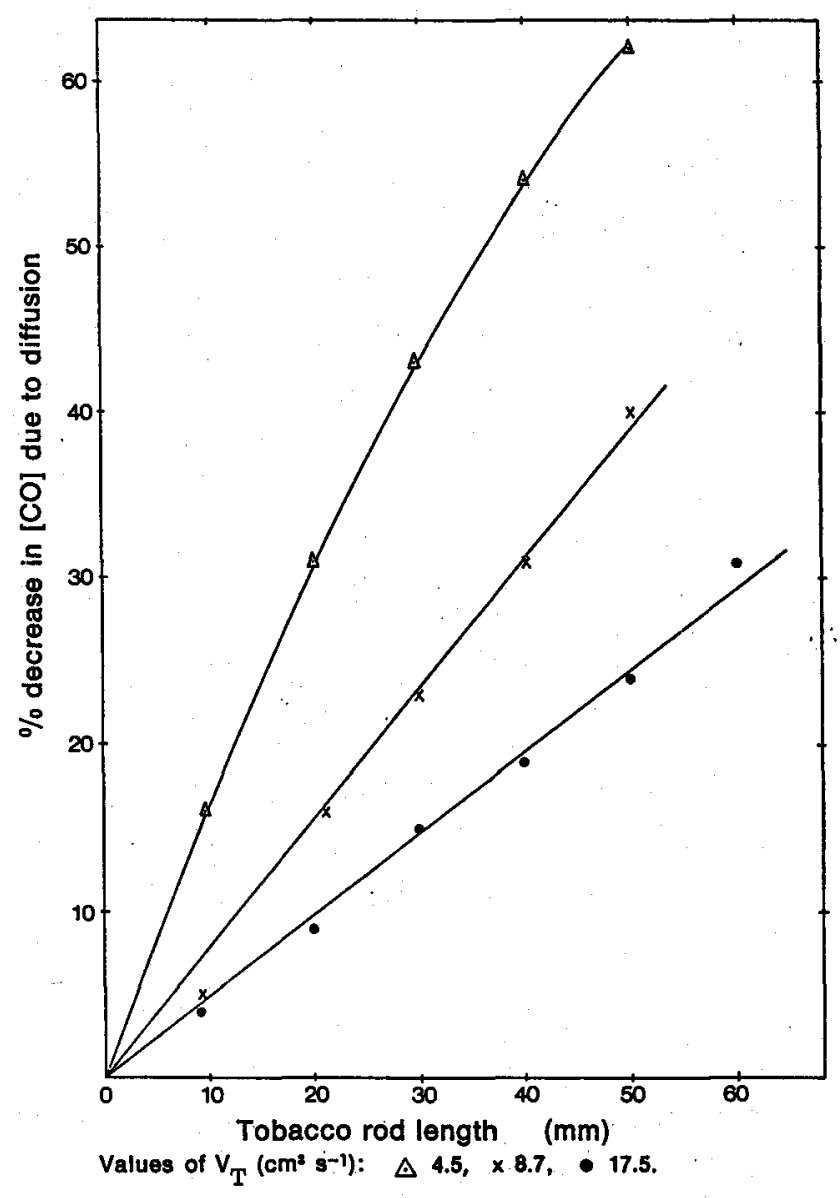


detail in this section. This investigation was conducted using the unlit tobacco rod/gas mixture system described earlier.

In the first part of the study, tobacco rods similar to those already examined (i.e. Virginia blend tobacco wrapped in paper of permeability about $70 \mathrm{~cm}^{3} \mathrm{~min}^{-1}$ $\left.\left(10 \mathrm{~cm}^{2}\right)^{-1}(10 \mathrm{~cm} \text { water })^{-1}\right)$ were tested at a variety of exposed tobacco rod lengths and gas flow rates. The extent to which dilution and diffusion occurred were measured under each set of conditions. The magnitude of dilution was measured directly from the tobacco rod input and outlet gas flow rates. The extent of diffusion was obtained from the reduction in carbon monoxide concentration in the outlet gases from the tobacco rod, as measured by the Bosch infra-red analyser, after correction for dilution.

The diffusion results are presented in Figure 5, and the dilution results in Figure 6 . The following conclusions can be drawn.

[a] The extent to which carbon monoxide diffuses out of tobacco rods is increased by increases in tobacco rod length and by decreases in gas flow rate. Thus, as much as $60-70 \%$ of the carbon monoxide formed behind the coal can diffuse out from the early puffs of cigarettes of king-size construction which contain sufficient filter ventilation to reduce flow rate through the coal to approximately $5 \mathrm{~cm}^{3} \mathrm{~s}^{-1}$. The exact consequences cannot be stated from these experiments, since neither thermal effects nor the influence of the coal impedance are considered in the unlit analogue.

[b] The extent to which carbon monoxide is diluted by inflowing air is also increased by increases in tobacco

Figure 6. Dllution of carbon monoxide in unllt tobacco rods at different $V_{T}$.

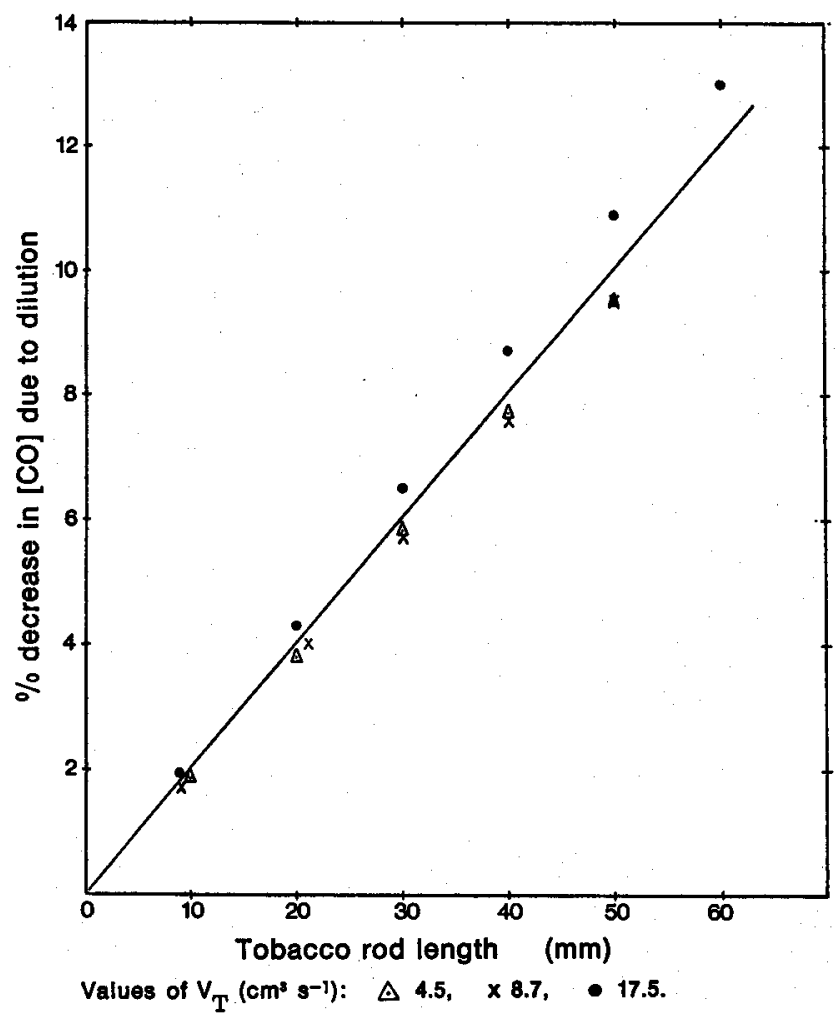

rod length, but is not significantly affected by changes in gas flow rate i.e. at a given rod length, the proportion of the flow composed of diluting air is almost independent of flow rate. On the basis of this data, $10-15 \%$ dilution of the early puffs will result when this paper is used. The proportion may be increased to some extent in lit cigarettes due to formation of the coal impedance (11).

[c] The relationships presented are approximately linear, in contrast to those in Figure 4. However, again this difference is due to the progressive formation of a coal impedance during the early puffs for lit cigarettes, resulting in increased dilution flow rates per $\mathrm{cm}$ length and causing non-linearity of the data presented in Figure 4.

By fixing the exposed tobacco rod length at $60 \mathrm{~mm}$ and $V_{T}$ at $17.5 \mathrm{~cm}^{8} \mathrm{~s}^{-1}$, the effect of changes in paper permeability on the extent of diffusion and dilution was studied. Two cigarette paper types were investigated inherently porous papers and electrostatically perforated papers. The perforated papers were prepared from the least inherently permeable paper, i. e. the base paper permeability of the perforated papers was about $70 \mathrm{~cm}^{8}$ $\mathrm{min}^{-1}\left(10 \mathrm{~cm}^{2}\right)^{-1}(10 \mathrm{~cm} \text { water })^{-1}$. The results are presented in Figures 7 and 8 , from which the following conclusions have been drawn.

[a] The decrease in carbon monoxide due to diffusion can, under the conditions of the experiment, be increased from about $30 \%$ to about $40 \%$ by increasing the permeability of inherently porous paper from about 70 to about $1000 \mathrm{~cm}^{3} \mathrm{~min}^{-1}\left(10 \mathrm{~cm}^{2}\right)^{-1}(10 \mathrm{~cm} \text { water })^{-1}$. The value at a permeability of $250 \mathrm{~cm}^{3} \mathrm{~min}^{-1}\left(10 \mathrm{~cm}^{2}\right)^{-1}$ (10 $\mathrm{cm}$ water) $)^{-1}$, namely $32 \%$, agrees well with Waltz and Häusermann's (4) estimate of $35 \%$ for early puffs.

[b] The total quantity of carbon monoxide which diffuses out of the tobacco rod is decreased by the introduction into the paper of perforations, and little affected by changes in the level of perforation. This observation is discussed later in the paper.

[c] At a given paper permeability, more diluting air is admitted through perforated paper than inherently porous paper. This apparently anomalous result can be readily accounted for as follows. The flow/pressure relationship across inherently porous paper is linear (12), while that across perforated paper is not (13). Consider two papers of identical overall permeability, one inherently porous and the other perforated. When the pressure differential across $10 \mathrm{~cm}^{2}$ of either paper is $10 \mathrm{~cm}$ water, the flow is $V_{1} \mathrm{~cm}^{3} \mathrm{~min}^{-1}$ for both papers (Figure 9). When wrapped round a cigarette, the average pressure differential across the paper during smoking is less than $10 \mathrm{~cm}$ water (14). Thus, from Figure 9 it is seen that for a pressure differential $P$, the flow through the perforated paper $\left(V_{2}\right)$ is greater than the flow through the inherently porous paper $\left(\mathrm{V}_{3}\right)$. Consequently, in a cigarette the amount of diluting air drawn through the paper will be greater with the perforated paper, as shown by the results in Figure 8. 
Figure 7. Diffualon of carbon monoxide out of unilt tobacco rods through papers of different permeabilitles.

Paper type: $\odot$ inherently porous, + electrostatically perforated.

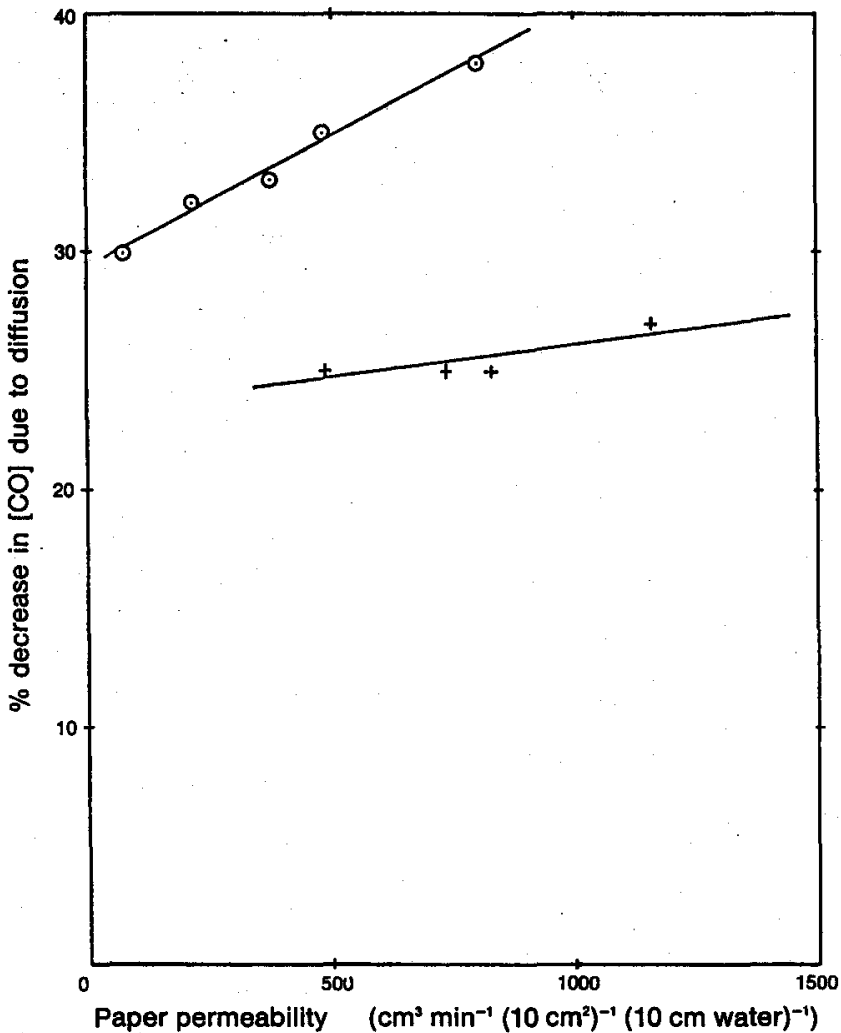

Since, at a given paper permeability (as assessed by a standard permeability tester) perforated papers permit less outward diffusion but allow more inward dilution than inherently porous papers, their overall effects on carbon monoxide delivery from the cigarette can be quite similar.

The effect of external air movement was investigated using the unlit cigarette system. For this study, the least

Flgure 9. Air flow/pressure relationship across paper.

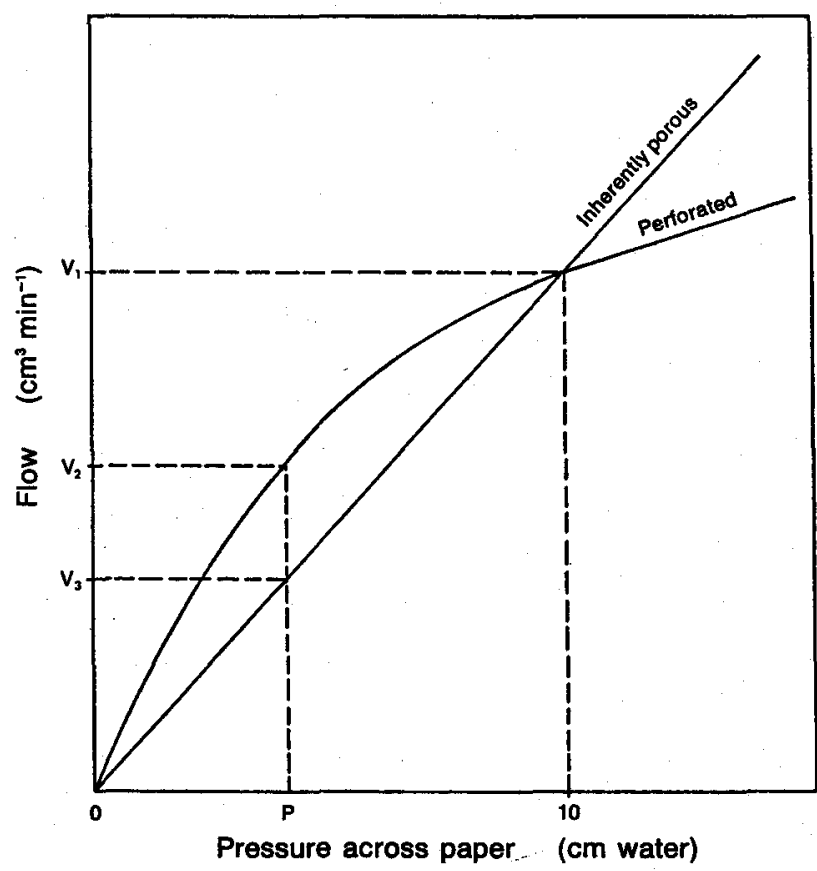

Figure 8. Dllution of carbon monoxide in unilt tobacco rods through papers of different permeabilitles.

Paper type: $\odot$ inherently porous, + electrostatically perforated.

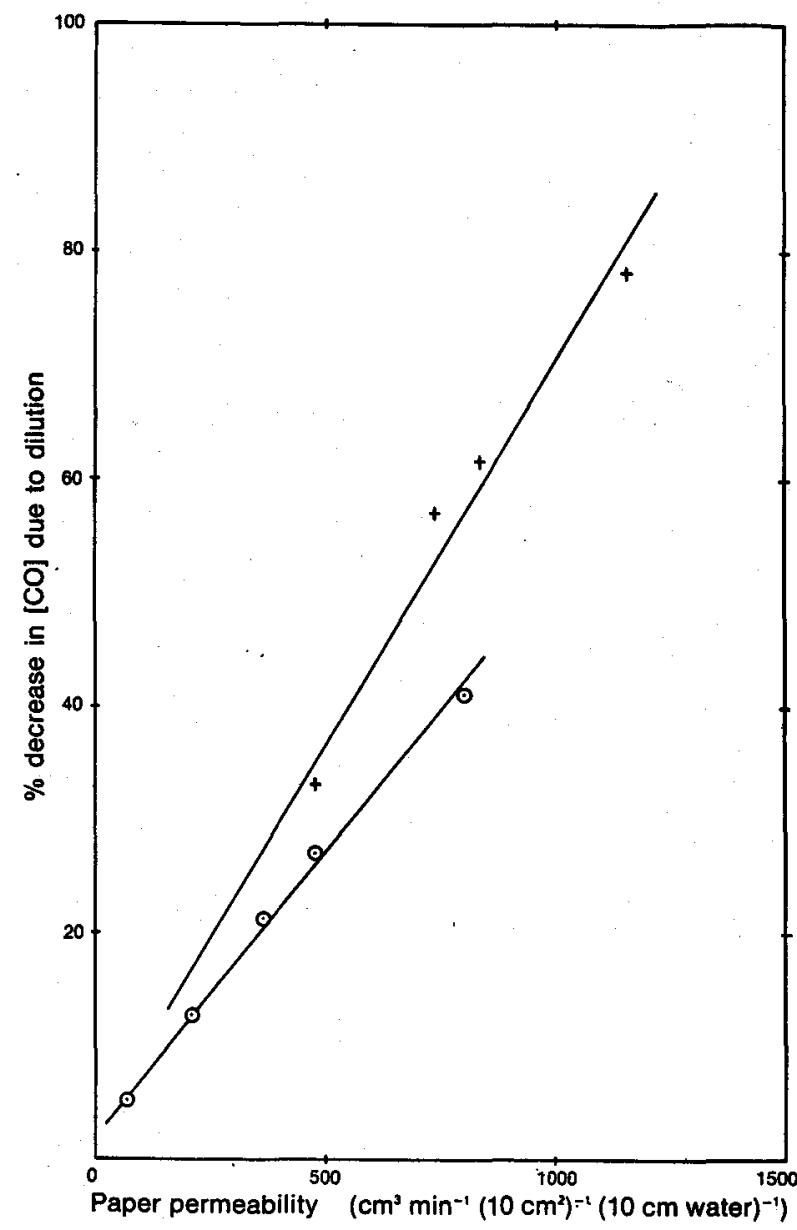

inherently porous paper was again used, and the exposed rod length was fixed at $50 \mathrm{~mm}$. For different rod flow rates $\left(V_{T}\right)$, the effect of external air flow on diffusion was assessed. The results (presented in Figure 10) show the extent to which carbon monoxide diffusion can be enhanced by external draughts. This indicates that diffusion away from the outer surface of the paper is a significant component of the overall diffusion coefficient $(G)$ determined for cigarettes. For a flow rate, $V_{T}$, of $17.5 \mathrm{~cm}^{3} \mathrm{~s}^{-1}$ out of the cigarette, the carbon monoxide diffusion out of the cigarette is increased from $22 \%$ to $38 \%$ (i. e. almost doubled) as the external air speed round the cigarette is raised from 0 to $150 \mathrm{~cm} \mathrm{~s}^{-1}$. It is seen from the results in Figure 10 that a large part of this increase occurs by relatively small increases in air speed under "calm" conditions on the Beaufort International scale of wind speeds (15). Thus the draught conditions under which cigarettes are smoked could have an important influence on the carbon monoxide delivery determined.

\section{Diffusion Coefficient of Carbon Monoxide Through Paper}

As outlined above, the carbon monoxide drawn down a cigarette escapes to the atmosphere by a three-stage 
Flgure 10. Diffusion of carbon monoxide out of unlit tobacco rods at different external alr flows. The Beaufort International descriptive terms for the wind speed are also given (15).

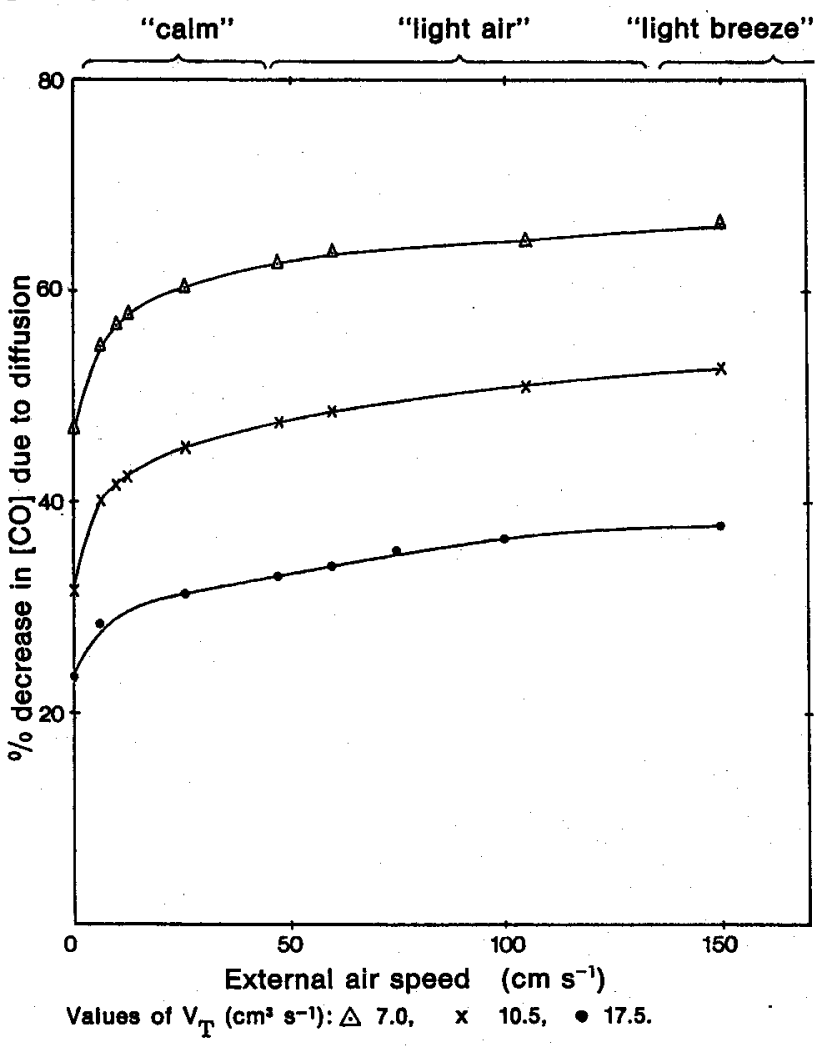

process: diffusion through the tobacco bed, diffusion through the cigarette paper, and diffusion away from the outer surface of the paper. In the above sections, the total diffusion out of the cigarette was considered in terms of an overall diffusion coefficient function, G. In the present section, diffusion through the cigarette paper is considered in isolation.

The diffusion coefficients through the paper of carbon monoxide in a carbon monoxide/nitrogen mixture have been measured using a specially constructed diffusion cell. Briefly, the cell consisted of two parallel compartments each of depth e $\mathrm{cm}$, separated by the paper under test, $\mathrm{L} \mathrm{cm}$ long, $\mathrm{b} \mathrm{cm}$ wide, and $\mathrm{x} \mathrm{cm}$ thick. A gaseous mixture of $c \% \mathrm{v} / \mathrm{v}$ of carbon monoxide in nitrogen flowed at $\mathrm{V} \mathrm{cm} \mathrm{cm}^{3} \mathrm{~s}^{-1}$ into one compartment of the cell, while nitrogen flowed at the same rate into the other compartment. As the gas streams flowed through the cell, diffusion through the paper occurred. The concentration difference $(\Delta c \% \mathrm{v} / \mathrm{v})$ between the two gases was measured as they emerged from the cell, under a variety of conditions of different gas flow rates, compartment depths, and lengths of paper exposed to the gas streams.

A mathematical model of the diffusion cell has been formulated, which yields an equation for the calculated value of $\Delta \mathrm{c} / \mathrm{c}$ in terms of the diffusion coefficient through the paper $\left(D_{p}, \mathrm{~cm}^{2} \mathrm{~s}^{-1}\right)$, and the experimental parameters, of the general form:

$$
\Delta c / c_{\text {calc }}=f\left(D_{p}, x, L, e, V\right) \text {. }
$$

For a given paper, $m$ observed values of $\Delta c / c$ are
Figure 11. Relationahlp between diffusion coefficient of carbon monoxlde through inherently porous paper $\left(D_{p}\right)$ and permeability (Z) of the paper.

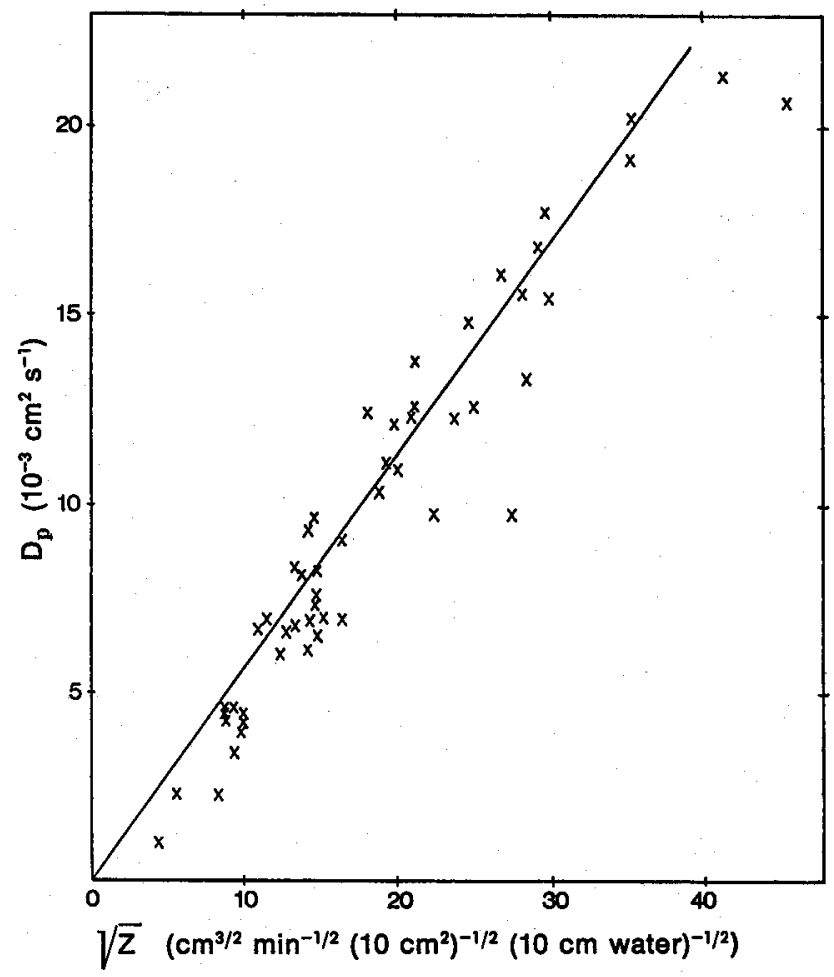

obtained by varying the experimental parameters, outlined above. A computer program has been written which adjusts the value of $D_{p}$ between $1 \times 10^{-4}$ and $0.2 \mathrm{~cm}^{2} \mathrm{~s}^{-1}$ so as to minimise $\mathrm{S}$ by an iterative procedure, for a given set of data. The function $S$ is defined by equation 8 :

$$
S=\sum_{i=1}^{i=m}\left\{\left(\Delta c / c_{o b s}\right)_{i}-\left(\Delta c / c_{c a l c}\right)_{i}\right\}^{2} .
$$

The value of $D_{p}$ that gives a minimum value of $S$ is the quoted value of $D_{p}$.

For inherently porous cigarette papers with permeabilities up to about $2000 \mathrm{~cm}^{3} \mathrm{~min}^{-1}\left(10 \mathrm{~cm}^{2}\right)^{-1}(10 \mathrm{~cm}$ water $)^{-1}$, it was found that the diffusion coefficient of carbon monoxide through the paper was approximately proportional to the square root of the permeability. (Figure 11). This result is readily explicable using a simple model of the paper structure, as follows.

\section{Model of Paper Structure}

Electron microscope photographs of inherently porous cigarette paper show that it does not consist of discrete pores within a solid matrix, but is made up of an interlocking network of cellulose fibres interspersed with chalk particles. The flow of air through the structure is governed by viscous forces. However, previous studies have shown that at near atmospheric pressure, the paper can be treated as a bundle of parallel capillary tubes for the flowing gas $(16,17)$. The diameter of these "formal pores" is much less than the paper thidkness. The flow through each tube is governed by the Poisenille 
law, so that the flow $\left(\mathrm{V}, \mathrm{cm}^{3} \mathrm{~s}^{-1}\right)$ through $\mathrm{A} \mathrm{cm}$ of paper is given by:

$$
\mathrm{V}=\frac{\pi \mathrm{PA}}{8 \eta} \sum\left\{\frac{\mathrm{j}_{\mathrm{i}} \mathrm{r}_{\mathrm{i}}^{4}}{\ell}\right\}
$$

where

$j_{i}$ is the number of formal pores of radius $r_{i}(\mathrm{~cm})$ and tortuous length $/(\mathrm{cm})$, per $\mathrm{cm}^{2}$ of paper,

$P$ is the pressure differential across the paper (dyne $\mathrm{cm}^{-2}$ ), and

$\eta$ is the viscosity of air flowing through the paper, $=1.85 \times 10^{-4}$ poise at $24^{\circ} \mathrm{C}(18)^{*}$.

Darcy's law (19) for the flow of a fluid through a porous medium is:

$$
V=B_{1} A \frac{P}{x}
$$

where

$B_{1}$ is the permeability of the material $\left(\mathrm{cm}^{3} \mathrm{~s} \mathrm{~g}^{-1}\right)$ and $x$ is the thickness of the material $(\mathrm{cm})$.

Comparing equations 9 and 10 gives:

$$
\frac{B_{1}}{x}=\frac{\pi}{8 \eta} \sum\left\{\frac{j_{i} r_{i}^{4}}{l}\right\}
$$

The factor $B_{1} / x$ (units $\mathrm{cm}^{2} s \mathrm{~g}^{-1}$, equivalent to $\mathrm{cm}^{3} \mathrm{~s}^{-1}$ $\left(\mathrm{cm}^{2}\right)^{-1}$ (dyne $\left.\mathrm{cm}^{-2}\right)^{-1}$ ) can be converted to paper permeability ( $Z$, units $\left.\mathrm{cm}^{3} \mathrm{~min}^{-1}\left(10 \mathrm{~cm}^{2}\right)^{-1}(10 \mathrm{~cm} \text { water })^{-1}\right)$ simply by scaling of units. Since the tortuous path lengths of the formal pores are not known, it must be assumed that the lengths of all pores in a given paper are equal to the paper thickness. Hence, by scaling units, equation 11 becomes:

$$
\mathrm{Z}=\frac{1.25 \times 10^{10}}{\mathrm{x}} \sum\left(\mathrm{j}_{\mathrm{i}} \mathbf{r}_{\mathrm{i}}^{4}\right)
$$

Taking a bulk view of the diffusion of a gas through paper, Fick's law for one-dimensional diffusion is given by:

$$
\frac{\mathrm{dn}}{\mathrm{dt}}=-\mathrm{AD}_{\mathrm{p}} \frac{\Delta[\mathrm{n}]}{\mathrm{x}}
$$

where

$\mathrm{dn} / \mathrm{dt}$ is the rate of diffusion of the gas in a twocomponent mixture through the paper $\left(\mathrm{mol} \mathrm{s}^{-1}\right)$,

A is the area of cross section of paper $\left(\mathrm{cm}^{2}\right)$ through which diffusion occurs,

$D_{p} \quad$ is the diffusion coefficient of the gas through the paper $\left(\mathrm{cm}^{2} \mathrm{~s}^{-1}\right)$, and

$\Delta[\mathrm{n}] / \mathrm{x}$ is the concentration gradient of the gas across the paper $\left(\mathrm{mol} \mathrm{cm}^{-4}\right)$.

\footnotetext{
* This value is not very temperature dependent at near-room temperatures - $\eta$ increases by less than $2 \%$ as the temperature is increased from 20 to $30{ }^{\circ} \mathrm{C}(18)$.
}

Diffusion through the paper can physically only take place through the pores in the paper**, and Fick's law for diffusion through the porous solid is:

$$
\frac{\mathrm{dn}}{\mathrm{dt}}=-\mathrm{AD}_{\mathrm{g}} \pi \Delta[\mathrm{n}] \Sigma\left\{\frac{\mathrm{j}_{\mathrm{i}} \mathrm{r}_{\mathrm{i}}^{2}}{\ell}\right\},
$$

where $D_{g}$ is the diffusion coefficient of the gas in a binary gas mixture $\left(\mathrm{cm}^{2} \mathrm{~s}^{-1}\right)$.

Comparing equations 13 and 14 gives:

$$
\mathrm{D}_{\mathrm{p}}=\frac{\pi \mathrm{D}_{\mathrm{g}}}{\mathrm{k}_{\mathrm{D}}} \sum\left(\mathrm{j}_{\mathrm{i}} \mathrm{r}_{\mathrm{i}}^{2}\right),
$$

where $\mathrm{k}_{\mathrm{D}}(=\ell / \mathrm{x})$ is the tortuosity factor for the pores for the diffusive mass transfer.

The pore size distribution of the "capillary" pores naturally present in the paper can be determined using a liquid-displacement method developed by Corte (17, 20-23). Although the results obtained with cigarette paper implied that the method had distorted the distribution being measured by opening up pores which were usually closed at the pressures encountered for air flow, it was found that the pore sizes in cigarette paper were more uniform than is generally found for coarser paper. Consequently, the terms $\Sigma\left(j_{i} r_{i}^{n}\right)$ in equations 12 and 15 can be approximately replaced by $\mathrm{jr}^{\mathrm{n}}$, where $\mathrm{j}$ is the number of formal pores of mean radius $\mathrm{r}$ per $\mathrm{cm}^{2}$ of paper. Thus comparison of equations 12 and 15 predicts that $D_{p}$ should be approximately proportional to $\sqrt{Z}$, as observed (Figure 11).

\section{Predicted Effect of Perforation on Diffusion Coefficient Through Paper}

Using the equations developed above, the effect of perforations on the diffusion coefficient of a gas through the paper can be predicted. In order to do this exactly, the precise pore size distribution of the "capillary pores" naturally present in the paper should be known. As mentioned above, the liquid displacement method of determining the pore size distribution in cigarette paper distorted the distribution being measured by opening up pores which were usually closed at the low pressures encountered for air flow. Analysing the effect of this distortion on the calculated paper permeability and diffusion coefficient suggested that for typical cigarette paper of permeability $100 \mathrm{~cm}^{3} \mathrm{~min}^{-1}\left(10 \mathrm{~cm}^{2}\right)^{-1}(10 \mathrm{~cm}$ water) $)^{-1}$, the "capillary pores" had a mean diameter of $1.5 \mu \mathrm{m}$. Thus, assuming that the paper consists of uniform pores of this diameter, equation 12 above indicates that for paper of permeability $100 \mathrm{~cm}^{3} \mathrm{~min}^{-1}\left(10 \mathrm{~cm}^{2}\right)^{-1}$ (10 cm water) $)^{-1}$, there are $9.35 \times 10^{5}$ pores per $\mathrm{cm}^{2}$ of paper. Thus from equation 15, assuming the tortuosity factor for the pores is 1 , the value of $D_{p}$ for carbon

\footnotetext{
** Strictly speaking, small gas molecules can diffuse through a.solid lattice and between the polymer chains in a fibre. However, for carbon monoxide and the cellulose and chalk structures of cigarette tissue, such diffusion will be infinitesimally slow compared to diffusion through the pores.
} 
monoxide diffusion* through the paper is $3.47 \times 10^{-9}$ $\mathrm{cm}^{2} \mathrm{~s}^{-1}$. This is somewhat smaller than the observed value for paper of this permeability, $4.5 \times 10^{-8} \mathrm{~cm}^{2} \mathrm{~s}^{-1}$, but in view of the approximations made in the calculation it will suffice for the present example.

Consider this paper of base porosity $100 \mathrm{~cm}^{3} \mathrm{~min}^{-1}$ $\left(10 \mathrm{~cm}^{2}\right)^{-1}(10 \mathrm{~cm} \text { water })^{-1}$ to be electrostatically perforated with 150 perforations per $\mathrm{cm}^{2}$, each perforation hole having a radius of $4.6 \mu \mathrm{m}$. The resultant overall permeability of the paper would be $250 \mathrm{~cm}^{3} \mathrm{~min}^{-1}$ $\left(10 \mathrm{~cm}^{2}\right)^{-1}(10 \mathrm{~cm} \text { water })^{-1}$. From equation 15 , the predicted value of $D_{p}$ for carbon monoxide diffusion through the perforated paper is $3.49 \times 10^{-3} \mathrm{~cm}^{2} \mathrm{~s}^{-1}$, which is only $0.6 \%$ higher than that predicted through the unperforated paper. The observed value of $D_{p}$ through such a perforated paper is $4.5 \times 10^{-3} \mathrm{~cm}^{2} \mathrm{~s}^{-1}$, the same value as that observed through the unperforated base paper.

Thus, the diffusion coefficient of a gas through perforated paper is virtually the same as that through the unperforated paper. In addition to this effect, when the perforated paper is wrapped round a cigarette and the cigarette is smoked, Imazu has shown mathematically that the perforation holes approximate to nozzles, and the inward air velocity through them is so large that it counterbalances the diffusion occurring in the opposite direction. On the other hand, the "pores" present in inherently porous paper act as capillaries, and Imazu has shown that the carbon monoxide diffusion through them is only reduced by about $10 \%$ by the inward flow of air.

\section{SUMMARY}

In some cigarette designs, diffusion of carbon monoxide out of a cigarette as the gases are drawn from their formation region towards the mouth end of the cigarette is more important than air dilution in controlling carbon monoxide mainstream delivery. The diffusion is a three-stage process: radial diffusion through the tobacco bed, diffusion through the paper, and diffusion away from the outer surface of the paper. Measurements have been made of the diffusion coefficient of carbon monoxide through paper, and the diffusion coefficient from the cigarette. The former has a value of $4.4 \times 10^{-3} \mathrm{~cm}^{2} \mathrm{~s}^{-1}$ for paper of permeability $70 \mathrm{~cm}^{3} \mathrm{~min}^{-1}\left(10 \mathrm{~cm}^{2}\right)^{-1}$ (10 $\mathrm{cm}$ water $)^{-1}$, whereas the latter has the much lower values of 1.5 to $1.9 \times 10^{-3} \mathrm{~cm}^{2} \mathrm{~s}^{-1}$ (dependent on external air movement) for an unlit cigarette wrapped in the same paper. In a lit cigarette, the combined diffusion coefficient is increased by about $50 \%$, due to thermal effects.

The diffusion of carbon monoxide away from the outer surface of the paper is a significant component of the overall diffusion coefficient determined for cigarettes. This diffusion rate is affected by the external air movement round the cigarette. Thus the draught conditions

\footnotetext{
- For a binary mixture of carbon monoxide and nitrogen at $23{ }^{\circ} \mathrm{C}$ and 1 atm pressure, $D_{g}=0.21 \mathrm{~cm}^{2} \mathrm{~s}^{-1}(24)$.
}

under which cigarettes are smoked could have an important influence on the carbon monoxide delivery determined.

For inherently porous cigarette papers, the diffusion coefficient of carbon monoxide through the paper is approximately proportional to the square root of permeability. For a perforated paper, the diffusion coefficient is dependent on the permeability of the base (unperforated) paper, and virtually independent of the degree of perforation. These observations are explicable using a simple model of the paper structure.

\section{ZUSAMMENFASSUNG}

Manche Cigaretten sind zur Steuerung der Ausbeute des Hauptstromrauches an Kohlenmonoxid so gestaltet, daß die Diffusion des Kohlenmonoxids aus der Cigarette heraus, während die Gase von ihrem Entstehungsort zum Mundstïdksende gezogen werden, größer ist als die Verdünnung des Rauchstromes durch Luft. Der Diffusionsprozeß besteht aus den folgenden drei Stufen: die radiale Diffusion durch den Tabak, die Diffusion durch das Papier und die Diffusion von der äußeren Papieroberfläche nach außen. Die Koeffizienten der Diffusion des Kohlenmonoxids durch das Papier hindurch und von der Cigarettenoberfläche nach außen wurden gemessen. Bei einer Papierporosität von $70 \mathrm{~cm}^{3} \mathrm{~min}^{-1}\left(10 \mathrm{~cm}^{2}\right)^{-1}$ (10 $\mathrm{cm}$ Wasser) $)^{-1}$ beträgt der erstere $4,4 \times 10^{-3} \mathrm{~cm}^{2} \mathrm{~s}^{-1}$, während der letztere (in Abhängigkeit von der äußeren Luftbewegung) bei einer nicht brennenden Cigarette mit dem gleichen Papier den viel niedrigeren Wert von 1,5 bis $1,9 \times 10^{-8} \mathrm{~cm}^{2} \mathrm{~s}^{-1}$ hat. In einer brennenden Cigarette erhöht sich der kombinierte Diffusionskoeffizient durch thermische Effekte um etwa 50\%.

Die Diffusion des Kohlenmonoxids von der äußeren Papieroberfläche nach außen macht bei der Bestimmung des Gesamtdiffusionskoeffizienten einer Cigarette einen bedeutenden Teil aus. Die Geschwindigkeit dieser Diffusion wird durch die die Cigarette umgebenden äußeren Luftbewegungen beeinträchtigt. Bei der Bestimmung der Ausbeute an Kohlenmonoxid kann es daher von großem Einfluß sein, unter welchen Zugluftbedingungen die Cigarette abgeraucht wird.

Bei in sich porösem Cigarettenpapier ist der Koeffizient der Diffusion des Kohlenmonoxids durch das Papier hindurch der Quadratwurzel der Durchlässigkeit ungefähr proportional. Bei perforiertem Papier ist der Diffusionskoeffizient von der Durchlässigkeit des zugrunde liegenden (unperforierten) Papiers abhängig und tatsächlich unabhängig vom Grad der Perforation. Diese Beobachtungen sind aufgrund eines einfachen Modells der Papierstruktur erklärbar.

\section{RESUME}

Dans le but de contrôler le rendement du flux principal de fumée en monoxyde de carbone, certaines sortes de cigarettes sont conçues de façon que, pendant que les gaz 
sont entraînés depuis la région de leur formation jusqu’à l'extrémité bouche de la cigarette, la diffusion du monoxyde de carbone vers l'extérieur de la cigarette soit plus importante que la dilution du flux de fumée avec de l'air. La diffusion se fait en trois étapes: la diffusion radiale à travers les couches de tabac, la diffusion à travers le papier et la diffusion vers l'extérieur à partir de la surface du papier. On a pris des mesures du coefficient de la diffusion du monoxyde de carbone à travers le papier, et du coefficient de la diffusion vers l'extérieur de la cigarette. Le premier donne une valeur de $4,4 \times 10^{-3}$ $\mathrm{cm}^{2} \mathrm{~s}^{-1}$ pour un papier d'une perméabilité de $70 \mathrm{~cm}^{3}$ $\min ^{-1}\left(10 \mathrm{~cm}^{2}\right)^{-1}(10 \mathrm{~cm} \text { d'eau })^{-1}$, tandis que le deuxième atteint une valeur inférieure de $1,5 \mathrm{a} 1,9 \times 10^{-3} \mathrm{~cm}^{2} \mathrm{~s}^{-1}$ (dépendant du mouvement de l'air environnant) pour une cigarette non allumée enveloppée dans le même papier. Dans une cigarette allumée, le coefficient combiné de diffusion a augmenté d'environ $50 \%$, da $a$ des eff ets thermiques.

La diffusion du monoxyde de carbone vers l'extérieur, partant de la surface du papier est une composante significative dans la détermination du coefficient de diffusion totale des cigarettes. La vitesse de cette diffusion est influencée par le mouvement de l'air autour de la cigarette. Donc les conditions de courants d'air, sous lesquelles les cigarettes sont fumées, peuvent influencer considérablement la détermination du rendement en monoxyde de carbone.

Dans le cas de cigarettes entourées de papier de porosité inhérente, le coefficient de la diffusion du monoxyde de carbone dे travers le papier est approximativement proportionnel à la racine carrée de la perméabilité. Dans le cas d'un papier perforé, le coefficient de diffusion dépend de la perméabilité du papier de base (non perforé), et est virtuellement indépendant du degré de perforation. Il est aisé d'expliquer ces observations à l'aide d'une maquette simple de la structure du papier.

\section{REFERENCES}

1. Newsome, J. R., and C. H. Keith: Tobacco Science 9 (1965) 65.

2. Baker, R. R., and K. D. Kilburn: Beitr. Tabakforsch. 7 (1973) 79.

3. Lanzillotti, H. V., and A. R. Wayte: Beitr. Tabakforsch. 8 (1975) 219.

4. Waltz, P., and M. Häusermann: Beitr. Tabakforsch. 3 (1965) 169.

5. Morie, G. P.: Tobacco Science 20 (1976) 174.
6. Owen, W. C., and M. L. Reynolds: Tobacco Science 11 (1967) 14.

7. Imazu, T.: Scientific Papers of the Central Research Institute, Japan Monopoly Corporation No. 113 (1971) 131 and 139.

8. Hedge, $R$. W.: Unpublished results.

9. Williamson, T. G., D. P. Batala, R. W. Jenkins and A. F. Frisch: Trans. Am. nucl. Soc. 21 (1975) 134.

10. Baker, R. R.: Nature 247 (1974) 405.

11. Baker, R. R.: Beitr. Tabakforsch, 8 (1975) 124.

12. Lipp, G., and $H$. van Nooy: Beitr. Tabakforsch. 1 (1962) 369.

13. Lipp, G.: Beitr. Tabakforsh. 3 (1966) 477.

14. Baker, R. R.: Nature 264 (1976) 167.

15. Encyclopaedia Britannica, 1957 edition, Vol. 3, p. 272.

16. Carson, F. T.: J. Res. Nat. Bur. Stand. 24 (1940) 435.

17. Corte, H.: The porous structure of paper, pp. 301331 of: Fundamentals of papermaking fibres, edited by F. Bolam; Technical Section of B. P. B. M. A., London, 1958.

18. Handbook of chemistry \& physics, edited by R. C. Weast; The Chemical Rubber Co., Cleveland, Ohio, 56th edition, 1975-76, Pp. F56-F59.

19. Grove, D. M.: Permeability and flow studies, Chapter 4 of: Porous carbon solids, edited by R. L. Bond; Academic Press, London, 1967.

20. Corte, H.: Das Papier 13/14 (1955) 290.

21. Corte, H.: Das Papier 19 (1965) 346.

22. Corte, H.: Filtration and Separation 3 (1966) 396.

23. Leekley, R. M., and R. F. Tyler: Tappi 59 (1976) 131.

24. Fuller, E. N., P. D. Schettler and J. C. Giddings: Ind. and Eng. Chem. 58 (5) (1966) 19.

\section{Adenowledgements}

The contributions of the following are gratefully acknowledged: Drs. D. G. Drake and D. S. Riley (mathematics of the diffusion cell), Mr. R. B. Dagnall and Mr. H. Rice (computer program for diffusion cell), and Mr. G. O. Brooks, Mr. B. G. Bunn, Mr. F. J. Dashley and Mr. D. J. Dittridh (experimental measurements).

\section{Authors' address:}

Group Research and Development Centre, British-American Tobacco Co. Ltd., Regent's Park Road, Southampton SO9 1PE, England. 